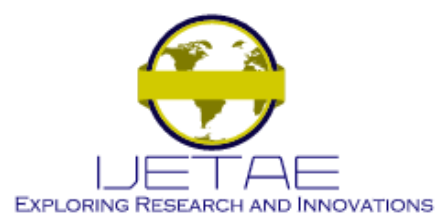

International Journal of Emerging Technology and Advanced Engineering

Website: www.ijetae.com (ISSN 2250-2459, ISO 9001:2008 Certified Journal, Volume 10, Issue 10, October 2020)

\title{
Simulation Study of Air Conditioning System Location in Commercial Kitchen
}

\author{
Mohammed Juma Al Areimi ${ }^{1}$, Anbu Clemensis Johnson ${ }^{2}$ \\ ${ }^{I}$ General Directorate of Muscat Municipality at Bushar, Department of Food Inspection and Monitoring, P.O. Box 609, P.C. \\ 112, Sultanate of Oman. \\ ${ }^{2}$ NUIST Reading Academy, 219 Ningliu Road, Nanjing, Jiangsu, 210044 P.R. China.
}

\begin{abstract}
Working in a commercial kitchen in restaurants and hotels is physically challenging. In the Middle East, summer temperatures are very high and require proper ventilation and air conditioning for comfortable working. In the current study a typical kitchen with dimensions $5 \mathrm{~m} \times 4 \mathrm{~m} \times 3 \mathrm{~m}$, with heat source and range hood is modelled using computational fluid dynamics software. A comparative analysis was conducted on the location of the air conditioning system in the kitchen space. The investigated locations of the air conditioning system were on the kitchen side wall and ceiling. The results of the simulation showed that placing the air conditioning system in the ceiling at the centre of the kitchen produced better air circulation. The air flow close to the hood had sufficient velocity to remove heat, contaminants and $\mathrm{CO}_{2}$ generated from the cooking process.
\end{abstract}

Keywords - Air conditioning, air velocity, carbon dioxide, hood, kitchen, simulation

\section{INTRODUCTION}

Food business is thriving all over the world because of the increase in population. Most of the food products are made in kitchens by culinary specialists. Working in confined spaces for long periods is demanding because of the heat, gases and fumes produced during food preparation [1]. The air quality is also affected due to the various toxic products released such as aldehydes and alkanoic acids produced from carbohydrates, proteins and fats in cooking [2]. The consequence from exposure to cooking fumes can range from minor effects on the respiratory system to respiratory cancer $[3,4]$. In order to reduce the undesirable effects from cooking, ventilation system is used and its primary function is to make the working environment more comfortable through adjusting air temperature, velocity, flow rate and humidity, and removal of contaminants for the safety of the working personnel [5]. The ventilation could be natural, mechanical, hybrid or mixed mode [6]. Mechanical ventilation is generally preferred in commercial kitchens because of space constraints. Various studies have been conducted to determine different parameters that control the comfort inside the kitchen.
In a study conducted by Manshoor et al. [7] using computational fluid dynamics (CFD) software of a kitchen space with dimensions $10 \mathrm{~m} \times 8 \mathrm{~m} \times 3 \mathrm{~m}$ showed that air velocity of $0.28 \mathrm{~m} / \mathrm{s}$ was required for working comfortably.

Size of the commercial and residential kitchens vary from place to place and are based on the space availability. It is a general practice to utilise the maximum available space for customers dining and use relatively less space for the food preparation room. Exhaust hood is commonly used as a kitchen ventilation system. The hoods used in kitchens can be of different types and is determined based on the quantity and different types of emission from cooking. The exhaust hood size is related to the cooking duty, which ranges from light duty $\left(200{ }^{\circ} \mathrm{C}\right)$ to extra heavy duty $\left(370{ }^{\circ} \mathrm{C}\right)$. Wall mounted range hoods are common in residential kitchens, due to lower installation cost and style based design variations. The air removed by the hood from the kitchen is replaced by makeup air to prevent negative pressure, and it is traditionally done through ceiling diffusers [8]. Proper design of hoods is essential for optimal performance. Simulation study by Rahman and Islam [9] has shown that using front and bottom hood extraction method extensively reduced the emissions and provided thermal comfort in the kitchen space.

Gas releases such as $\mathrm{CO}$ and $\mathrm{CO}_{2}$ from stoves coupled with poor ventilation can have serious health effects caused by oxygen deficiency and could be detrimental if exposed for a long period of time. Various studies have been carried out to optimise the parameters to reduce the build-up of gases from stoves. Use of efficient hood system can reduce the $\mathrm{CO}_{2}$ level to $500 \mathrm{ppm}$ [10]. Increasing the air vent velocity to $1.5 \mathrm{~m} / \mathrm{s}$ can reduce the $\mathrm{CO}_{2}$ concentration by $68.3 \%$ [11]. In addition to the gases, temperature also needs to be maintained. Study by Yuan et al. [12] has shown that using displacement ventilation can provide thermally comfortable environment. With increase in hood exhaust flow rate, heat and gas capture efficiencies also increases. The optimum air flow rate with maximum efficiency into the room from the ceiling was determined to be $100 \mathrm{~m}^{3} / \mathrm{h}[13]$. 


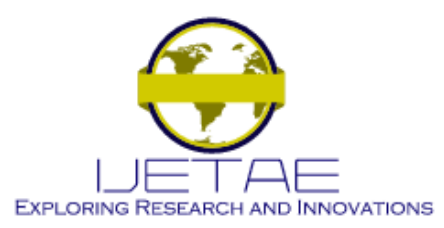

International Journal of Emerging Technology and Advanced Engineering

Website: www.ijetae.com (ISSN 2250-2459, ISO 9001:2008 Certified Journal, Volume 10, Issue 10, October 2020)

Similar type of study has shown that running an exhaust fan after cooking for 15 minutes had an impact similar to having $100 \mathrm{cfm}$ increase in air flow in the room [14].

In the Middle East, the outside temperature exceeds $40{ }^{\circ} \mathrm{C}$ during summer and installation of air conditioning system in the kitchen becomes essential. In commercial kitchens, large quantity of air is required and cooling the air requires significant amount of energy and without which it would be difficult to maintain a suitable environment for working. Study by Kondo et al. [15] has shown that outdoor air along with conditioned air can make the kitchen environment convenient. Appropriate positioning and location of the air conditioning system inside the kitchen is essential for creating a comfortable work environment. In the current simulation study temperature, air velocity and $\mathrm{CO}_{2}$ distribution in the kitchen with air conditioning system placed in two different locations are analysed.

\section{MAterials And Methods}

Gambit and Fluent software packages were used to model the air flow patterns. Physical properties of air were selected from the Fluent database. The two cases studied were,

Case 1: Kitchen with range hood and fixed heat source with air conditioning system placed on the side wall.

Case 2: Kitchen with range hood and fixed heat source with air conditioning system placed at the centre of the kitchen ceiling.

The simulated kitchen dimension was $5 \mathrm{~m} \times 4 \mathrm{~m} \times 3 \mathrm{~m}$ and the schematic sketch of the kitchen environment is presented in Figure 1. The boundary conditions applied are given in Table 1 . The kitchen geometry was imported as STL files into Fluent, meshed, and material properties were applied. The air flow pattern was simulated using a single phase model in which the wall temperature remained constant during the calculation. The single phase model was chosen so that the ventilation was performed under only air flow conditions, and to reduce the computation time. The wall boundary was set to a free slip condition and the RNG turbulence model was used. Heat transfer effects were also included in the model.

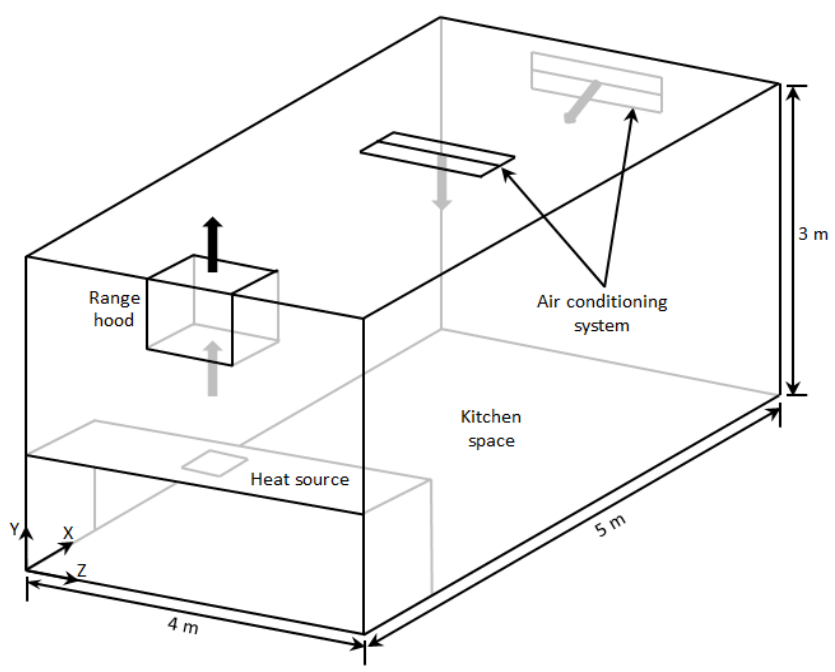

Figure 1. Schematic sketch of the simulated kitchen space.

Table 1.

Boundary conditions used in the kitchen space simulation.

\begin{tabular}{ccccc}
\hline $\begin{array}{c}\text { Boundary } \\
\text { Conditions }\end{array}$ & $\begin{array}{c}\text { Dimension } \\
(\mathbf{m})\end{array}$ & $\begin{array}{c}\text { Temperature } \\
(\mathbf{K})\end{array}$ & $\begin{array}{c}\text { Flow rate } \\
\left(\mathbf{m}^{\mathbf{3}} / \mathbf{s}\right)\end{array}$ & $\begin{array}{c}\text { Concentration } \\
(\text { Mass fraction) }\end{array}$ \\
\hline Range hood & $\begin{array}{c}0.20 \times 0.30 \times \\
0.30\end{array}$ & - & 1.10 & - \\
Heat source & $0.15 \times 0.15$ & 373 & - & - \\
Source $\mathrm{CO}_{2}$ & - & - & - & 0.20 \\
$\mathrm{AC} \mathrm{System}$ & $0.90 \times 0.10$ & 298 & 1.10 & - \\
Wall & - & $\begin{array}{c}\text { Adiabatic, } \\
\text { No slip }\end{array}$ & - \\
\hline
\end{tabular}

\section{RESUlts AND DisCUSSION}

\section{A. Case 1}

The results of the simulation are presented in the form of contour diagrams. Figure 2 shows the vertical section taken along the centre of the kitchen showing the temperature contour generated by the heat source in the presence of the working air conditioning system placed on the side wall. It can be seen that the temperature gradually decreases away for the heat source towards the side wall and the effect of the temperature is felt in the entire kitchen space. The air flow from the air conditioning system is directed towards the hood and its room cooling effect is reduced. 


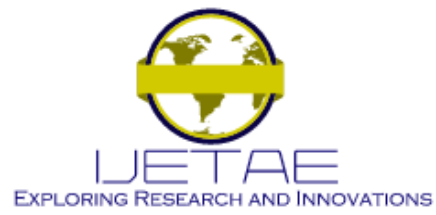

International Journal of Emerging Technology and Advanced Engineering

Website: www.ijetae.com (ISSN 2250-2459, ISO 9001:2008 Certified Journal, Volume 10, Issue 10, October 2020)

The upper section of the kitchen is cooler than the lower section because of the cool air from the air conditioning system, while the area close to the heat source is warm $\left(32{ }^{\circ} \mathrm{C}\right)$. The air flow velocity from the air conditioning system placed on the side wall is shown in Figure 3. It can be seen that the air flow from the air conditioning system is typically laminar and is directed towards the hood. The maximum velocity was $2.61 \mathrm{~m} / \mathrm{s}$ which decreased to about $0.64 \mathrm{~m} / \mathrm{s}$ close to the hood. Higher air velocity close to the hood is beneficial in removing the contaminants and air pollutants from the hot source. The current value of 0.64 $\mathrm{m} / \mathrm{s}$ in the close proximity of the hood is greater than the air velocity determined in the study by Manshoor et al. [7] for comfortable working. The $\mathrm{CO}_{2}$ concentration close to the heat source was maximum, which decreased significantly away from the source (Figure 4). The effect of $\mathrm{CO}_{2}$ on the person working close to the heat source would be substantial as it is dispersed around the breathing zone.
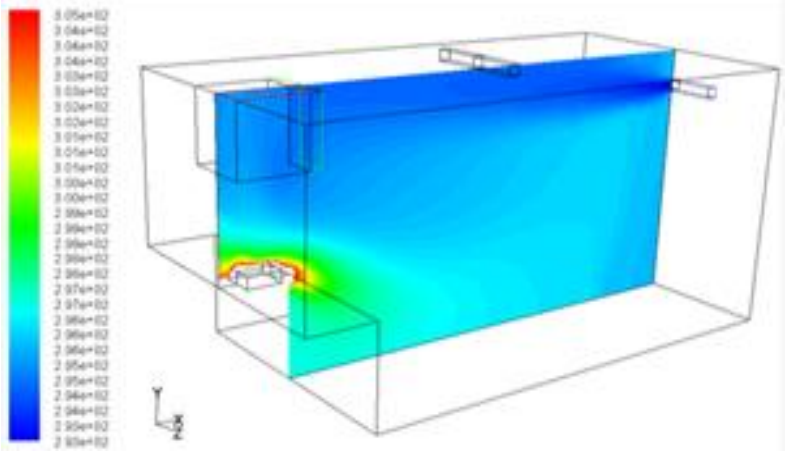

Figure 2. Vertical section of the temperature contour diagram with air conditioning system on the side wall.

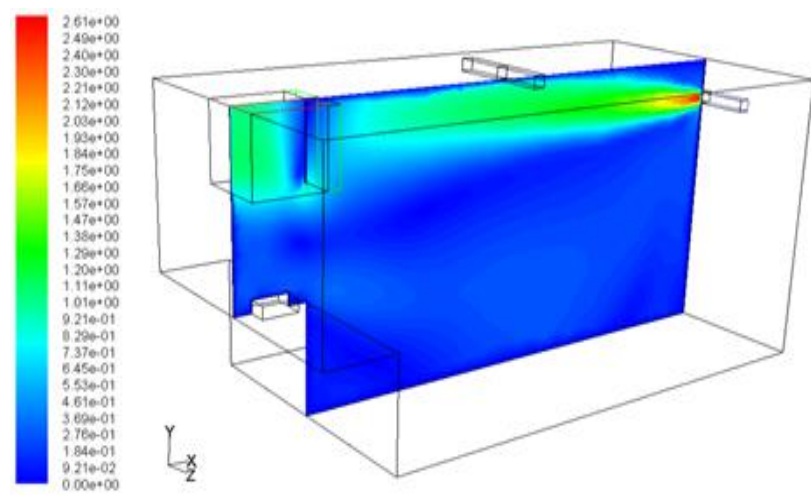

Figure 3. Vertical section of the air flow velocity contour diagram with air conditioning system on the side wall.

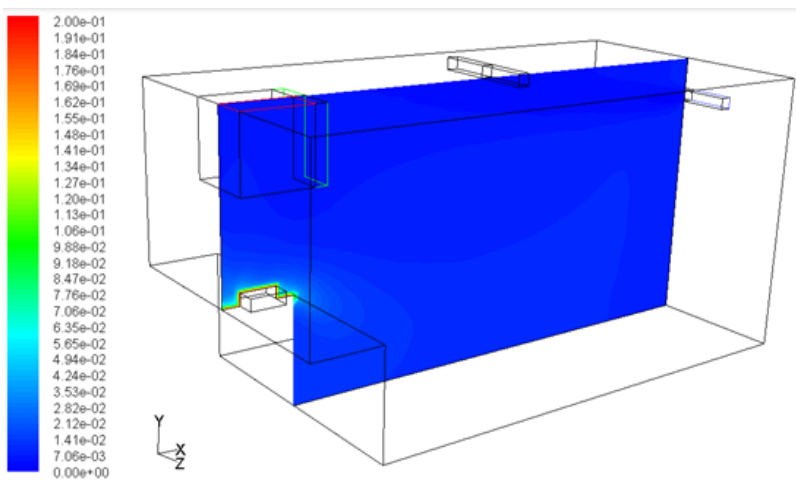

Figure 4. Vertical section of the $\mathrm{CO}_{2}$ contour diagram with air conditioning system on the side wall.

\section{B. Case 2}

Changing the location of the air conditioning system to the centre of the kitchen had a significant effect. The temperature variation contour diagram (Figure 5) shows that the room has two temperature zones, with higher temperature close to the heat source and standard room temperature in the region towards the side wall. The temperature gradient indicates the heat movement directly in the direction of the hood rather than in the direction of the kitchen space, this would make the working temperature of the kitchen more comfortable. The air flow velocity pattern in Figure 6 shows that high velocity air $(2.68 \mathrm{~m} / \mathrm{s})$ coming from the air conditioning system generates an updraft in the direction of the hood and causes a turbulent air circulation inside the kitchen. The air velocity close to the hood is sufficiently high $(\sim 0.66 \mathrm{~m} / \mathrm{s})$ to direct the air pollutants and contaminants released from the cooking process to the hood. Figure 7 illustrates the $\mathrm{CO}_{2}$ concentration variation in the kitchen. It can be seen that $\mathrm{CO}_{2}$ movement is directed upwards in the direction of the hood. This results in less exposure of people working close to the heat source to $\mathrm{CO}_{2}$, since the turbulent air flow movement will draw $\mathrm{CO}_{2}$ and other contaminants towards the hood. This is in accordance with the earlier study by Rahman, Islam and Amin [11].

When both cases are compared it is evident that the air conditioning system location in the kitchen had a significant impact. The heat flow from the hot source towards the hood is enhanced in Case 2. The location of the air conditioning system in Case 2 results in air flow velocity that is sufficient to direct the air flow from the region below the heat source to the hood facilitating the removal of contaminants and $\mathrm{CO}_{2}$ produced from the cooking process. 


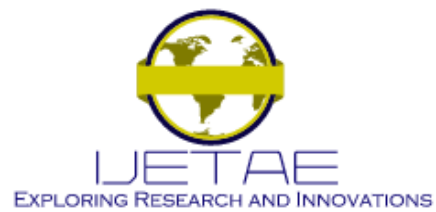

International Journal of Emerging Technology and Advanced Engineering Website: www.ijetae.com (ISSN 2250-2459, ISO 9001:2008 Certified Journal, Volume 10, Issue 10, October 2020)
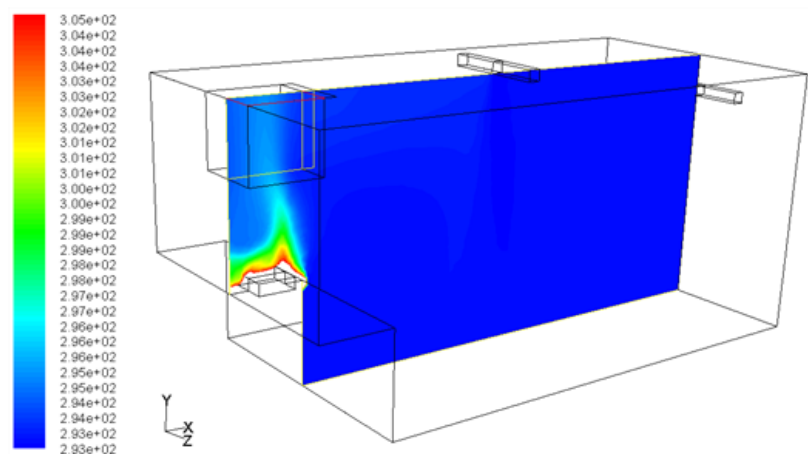

Figure 5. Vertical section of the temperature contour diagram with air conditioning system on the room ceiling.
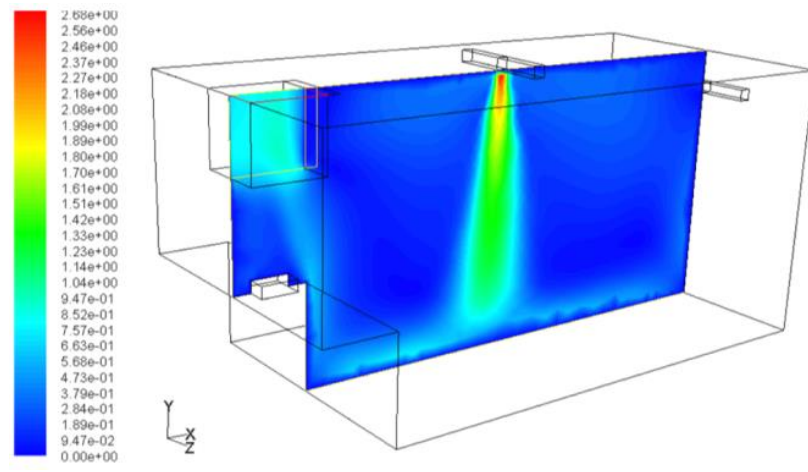

Figure 6. Vertical section of the air flow velocity contour diagram with air conditioning system on the room ceiling.
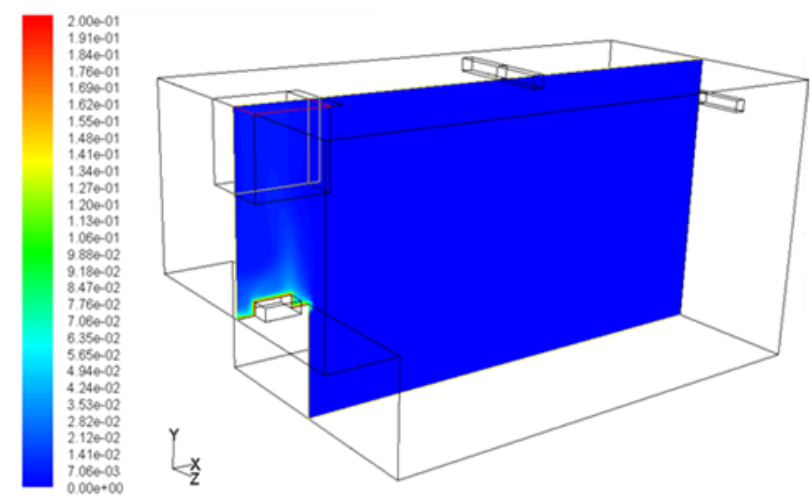

Figure 7. Vertical section of the $\mathrm{CO}_{2}$ contour diagram with air conditioning system on the room ceiling.

\section{CONCLUSION}

The kitchen environment was successfully simulated using the CFD software. The study conducted indicated that the location of the air conditioning system in the kitchen is crucial.
Placing the air conditioning system in the ceiling at the centre of the kitchen provided necessary ventilation around the heat source. The air velocity was sufficiently high to remove heat, contaminants and $\mathrm{CO}_{2}$ generated from the cooking process.

\section{Acknowledgements}

Mr. Mohammed Juma Al Areimi would like to thank Dr. Waleed Abdul Kareem for providing continuous support during the simulation work.

\section{REFERENCES}

[1] Keil, C.B., Kassa, H., and Kenny, F. 2004. Kitchen hood performance in food service operations. $\mathrm{J}$ of Environment Health. 67(5), 25-30.

[2] Robinson, A.L., Subramanian, R., Donahue, N.M., BernardoBricker, A., and Rogge, W.F. 2006. Source apportionment of molecular markers and organic aerosol. 3. Food cooking emissions. Environ Sci Technol. 40(24), 7820-7827.

[3] Svedahl, S., Svendsen, K., Qvenild, T., Sjaastad, A.K., and Hilt, B. 2009. Short term exposure to cooking fumes and pulmonary function. Journal of Occupational Medicine and Toxicology. 4(9), $1-8$.

[4] Yang, S.C., Jenq, S.N., Kang, Z.C., and Lee, H. 2000. Identification of benzo[a]pyrene 7,8-diol 9,10-epoxide N2-deoxyguanosine in human lung adenocarcinoma cells exposed to cooking oil fumes from frying fish under domestic conditions. Chem Res Toxicol. 13(10), 1046-1050.

[5] Saha, S., Guha, A., and Roy, S. 2012. Experimental and computational investigation of indoor air quality inside several community kitchens in a large campus. Building and Environment. $52,177-190$

[6] WHO. 2009. Guidelines for indoor air quality: Dampness and mould. Online

https://www.euro.who.int/_data/assets/pdf_file/0017/43325/E92645 .pdf, accessed 6 October 2020.

[7] Manshoor, B., Zaman, I., Asmuin, N., Ramlan, F., and Khalid, A. 2014. Optimizing of Make Up Air Performance for Commercial Kitchen Ventilation Improvement, in Proceedings of the ICPER 2014 - 4th International Conference on Production, Energy and Reliability, June 3-5, 2014, Kuala Lumpur, 1-5. Malaysia: MATEC Web of Conferences.

[8] ASHRAE Handbook. 2015. Heating, Ventilating, and AirConditioning Applications. Atlanta: ASHRAE.

[9] Rahman, M.H., and Islam, A.K.M.S. 2016. Effects of the Position of Kitchen Hood Suction on thermal Comfort and Carbon Dioxide Gas Emission from an Urban Residential Kitchen in Developing Countries. Applied Mechanics and Materials. 819, 117-121.

[10] Rahman, M.H., Islam, A.K.M.S., and Amin, M.R. 2014. Effects of Kitchen Hood System on Thermal Comfort and Carbon Dioxide Gas Emission from an Urban Residential Kitchen in Developing Countries, in Proceedings of the ASME 2014 International Mechanical Engineering Congress and Exposition, November 14-20, 2014, Quebec, 1-10. Montreal, Canada: ASME.

[11] Rahman, M.H., Islam, A.K.M.S., and Amin, M.R. 2015. Numerical Study of Carbon Dioxide Gas Emission From an Urban Residential Kitchen In Developing Countries. Journal of Thermal Science and Engineering Applications. 7(4), 041010. 


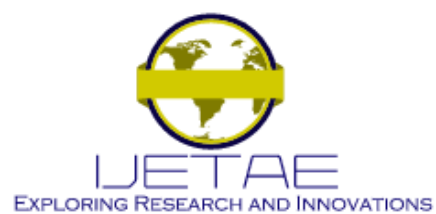

International Journal of Emerging Technology and Advanced Engineering Website: www.ijetae.com (ISSN 2250-2459, ISO 9001:2008 Certified Journal, Volume 10, Issue 10, October 2020)

[12] Yuan, J., Wang, L., He, Z., and Liu, X. 2013. The Research of Performance Comparison of Displacement and Mixing Ventilation System in Catering Kitchen. Journal of Environmental Protection. 4, 638-646.

[13] Yi, K.W., Kim, Y.I., and Bae, G.N. 2014. Effect of air flow rates on concurrent supply and exhaust kitchen ventilation system. Indoor and Built Environment. 0(0), 1-11.
[14] Dobbin, N.A. et al. 2018. The benefit of kitchen exhaust fan use after cooking - An experimental assessment. Building and Environment. 135, 289-296.

[15] Kondo, Y., Akabayashi, S.I., Nagase, O., and Matsuda, A. 1998. Numerical simulation of ventilation efficiency in commercial kitchen, in Proceedings of Roomvent 98: 6th International Conference on Air Distribution in Rooms, June 14-17, 1998, Stockholm, 1-8. Sweden: KTH Building Services Engineering. 